\title{
The effect of propylene glycol and polyethylene glycol 400 on physicochemical properties of peel off mask of nanosilver using bioreductor Sweet Orange Peels (Citrus sinensis L. Osbeck)
}

\author{
Dian Eka Ermawati*1, Fridha Angelina Pamuji ${ }^{2}$, Adi Yugatama ${ }^{2}$ \\ ${ }^{1}$ Depatrment of Pharmacy, Sekolah Vokasi, Universitas Sebelas Maret \\ Jl. Kolonel Sutarto No 150K, Jebres, Surakarta City, Central Java, Indonesia \\ ${ }^{2}$ Department of Pharmacy, Math and Natural Science Faculty, Universitas Sebelas Maret \\ Jl. Ir. Sutami 36A,Surakarta, Central Java,Indonesia
}

Submitted: 21-01-2021

Reviewed: 18-02-2021

Accepted: 23-04-2021

\begin{abstract}
Nanosilver (AgNPs) can be synthesized using plant extracts that safe, simple, and environmentally friendly. Sweet orange contains flavonoids and citric acid, which can be a bioreductor and capping agent in silver biosynthesis to increase antimicrobial activity. AgNPs are then dispersed in a gel for acne treatment through a peel-off mask preparation. Humectants provide moisture, prevent skin irritation and regulate the viscosity of the preparation. Propylene Glycol (PG) and Polyethylene Glycol 400 (PEG 400) are humectants combined to obtain good physicochemical properties of the preparation. This study aims to determine the character of AgNPs and the effect of humectant combinations on the physicochemical properties of peel-off mask preparations. AgNPs characterization was performed using UV-VIS Spectrophotometry, Particle Size Analysis, and Scanning Electron Microscope. The PG-PEG 400 combinations are F1 (0: 100\%); F2 (25\%: 75\%); F3 (50\%: 50\%); F4 (75\%: 25\%) and F5 (100\%: 0). The physicalchemical test for 28 days included organoleptic, viscosity, dry time, and $\mathrm{pH}$. The biosynthesis results produced AgNPs with maximum absorption of nanoparticles at $435 \mathrm{~nm}$, rod morphological shapes measuring $106 \pm 10.6 \mathrm{~nm}$, and PI $0.26 \pm 0.06$. Statistical analysis showed that the PG-PEG 400 combination significantly affected the viscosity, dispersibility, and dry time of the preparation but affected nothing to $\mathrm{pH}$. The combination of PG-PEG 400 decreased the viscosity and increased the dispersibility of peel-off mask preparation. The higher concentration of propylene glycol caused the dry time of preparation to become longer. Formulas with PG-PEG 400 combination of 25\%: $75 \%$ and $75 \%$ : $25 \%$ meet the requirements of viscosity, dispersibility, dry time, and $\mathrm{pH}$ and not significant changes during 28 days of storage at room temperature.
\end{abstract}

Keywords: AgNPs, propylene glycol, PEG 400, Peel-off mask, physicochemical properties

\footnotetext{
*Corresponding author:

Dian Eka Ermawati

Department of Pharmacy, Sekolah Vokasi, Universitas Sebelas Maret, Surakarta

J1. Kolonel Sutarto No 150K, Jebres, Surakarta City, Central Java, Indonesia

Email:dianekae@staff.uns.ac.id
} 


\section{INTRODUCTION}

Silver metal has been developed as an antibacterial agent in topical preparation, aiming to provide alternative treatments and reduce the risk of resistance by using topical antibiotics. Silver has mechanism action by breaking down the cell wall (Marx and Barillo, 2014) of gram-positive and gram-negative bacteria (Abbas and Sachin, 2012). The development of silver in the nanoparticle scale is intended to increase its effectiveness as an antimicrobial. Skin infections such as acne are characterized by normal flora found in blackheads, Staphylococcus epidermidis, and Staphylococcus aureus (Dreno et al., 2017). The anti-acne effect for skincare is more often formulated in topical dosage forms because the active substance will take longer to interact with facial skin.

The biosynthetic method using plant extracts is rapidly developing because it is environmentally friendly, practical, and simple (Prathna et al., 2011). According to the National Center for Biotechnology Information (2019), silver is more stable when stored in its salt form, so the silver used in this study is silver nitrate $\left(\mathrm{AgNO}_{3}\right)$. The biosynthesis process is conducted by boiling silver nitrate with sweet orange fruit peel (Citrus sinensis) to produce Nanosilver (AgNPs) with a particle size of $86.4 \mathrm{~nm}$ and diameter of inhibition zone to $S$. aureus bacteria of $28 \mathrm{~mm}$ (Annu et al., 2018). Inhibition zone diameters of more than $20 \mathrm{~mm}$ are in a strong category (Singh, 2013). The instruments used to ensure that AgNPs were formed in the biosynthesis process using plant extracts were UV-VIS Spectrophotometry and Particle Size Analysis.

AgNPs in cosmetics is safe according to the requirement of $20-200 \mathrm{~nm}$ particle size range because they may only penetrate the skin as deep as $2-3 \mu \mathrm{m}$ in the stratum corneum (the outermost part of the skin with a thickness of 15-20 $\mu \mathrm{m}$ ). Hence, it does not enter the systemic tract (Campbell et al., 2012). The accumulated AgNPs will disrupt the liver and spleen when it enters the systemic channel (Korani et al., 2011). The Science Committee on Consumer Safety (SCCS) limits silver exposure to the body not to exceed 10,000 ppm (Pulit-Prociak et al., 2019).

The peel-off mask was chosen as a delivery system for the AgNPs using bioreductor sweet orange peel as active ingredients because it has the advantage of being easily removed like an elastic membrane (Beringhs et al., 2013). Peel-off masks can increase the skin's hydration, possibly due to occlusion (blocking water loss from preparation) (Velasco et al., 2014). Cosmetics in peeloff masks are helpful in relaxing facial muscles, as a cleanser, freshener, moisturizer, and softener for facial skin (Vieira et al., 2009). The use of peel-off mask preparation is practical because it does not require rinsing. The peel-off mask formula components are closely related to humectants because humectants function to maintain the physical stability of the preparation by absorbing moisture from the environment and maintaining skin moisture by reducing water evaporation from the preparation (Vieira et al., 2009).

The peel-off mask of AgNPs using bioreductor sweet orange peel was formulated with humectant propylene glycol (PG) and polyethylene glycol (PEG 400) because they have the same function but different properties. PG is hygroscopic and water-soluble, so it can keep the mask preparation moist. PEG 400 is also chosen because it is hygroscopic and has a low viscosity. Thus, it is suitable for the physical properties expected from the gel preparation. PEG 400 also has good adhesion and distribution to the skin (Andini et al., 2017). Based on these physical properties, propylene glycol will produce a peel-off mask preparation with a long dry time, whereas PEG 400 will produce a stiff peel-off mask preparation. Therefore, a combination of PG and PEG 400 was carried out in the study to improve their function as a humectant and to produce a peel-off mask with a short dry time and an elastic film layer. PG with a 1-10\% concentration can increase penetration by modifying the stratum corneum's membrane barrier(Williams and Barry, 2004).

The peel-off mask of AgNPs using bioreductor sweet orange was made in five formulas with various concentrations of PG-PEG 400. The total humectant component that was used in the formula was $0.5 \% \mathrm{w} / \mathrm{w}$. Peel off masks of AgNPs using bioreductor sweet orange peel were made in five (5) formulas: F1 (0: 100\%); F2 (25\%: 75\%); F3 (50\%: 50\%); F4 (75\%: 25\%) and F5 (100\%: 
0 ). The AgNPs characteristic test was carried out using the spectrophotometer UV-VIS, PSA, and SEM methods. The physical and chemical properties of peel-off masks observed in this study were organoleptic tests, $\mathrm{pH}$, dry time, dispersibility, and viscosity, which were carried out for 28 days at room temperature.

\section{MATERIALS AND METHOD Materials}

Materials used in the study are: silver nitrate (Merck, Darmstadt, Germany), sweet citrus fruit harvested in Pacitan, East Java, Polyvinyl alcohol (Kurray Asia Pacific PTE LTD, Singapore), propylene glycol (DOW Chemical Pacific, Singapore), PEG 400 (PT. DOW Chemical, Indonesia), phenoxyethanol, aqua dest, fragrance (repackaged by CV Agung Jaya, Surakarta), and aqua dest (repackaged by PT Bratachem, Surakarta). Meanwhile, instruments used in the study are: analytical balance (Mettler Toledo AL204, d = 0.0001g, Columbus, Ohio), analytical balance (Precisa XB620C, $\mathrm{d}=0.01 \mathrm{~g}$, Moosmattstasse, Switzerland), modification of the scatter power tool, viscometer (Rion Viscotester VT-04: Kokubunji, Japan), centrifuge (Mini Spin Plus, Eppendorf AG: Germany), pH meter (Ohaus, Singapore) UV-Vis Spectrophotometer (GenesysTM, Thermo Fisher Scientific: USA), incubator (Memmert IN30, Memmert: Germany), Particle Size Analyzer (PSA) (HORIBA: USA), Scanning Electron Microscope (SEM) (FEI Quanta 200: USA).

\section{Methods}

\section{Sample preparation}

Identification of sweet citrus plants was carried out at the Biology Laboratory, Faculty of Math and Natural Sciences, Universitas Muhammadiyah Surakarta. Fresh orange peels were washed using aqua dest, then were weighed for 10 grams, and $250 \mathrm{~mL}$ of aqua dest were added. The mixture was heated at $60{ }^{\circ} \mathrm{C}$ for 30 minutes. The infusion is filtered using Whatman No. 1 filter paper (Annu et al., 2018). Silver nitrate $4.0 \mathrm{mM}$ solution: $680 \mathrm{mg}$ of silver nitrate were weighed, then were mixed with distilled water in a volumetric flask until the volume reached 1.0 liters.

\section{Nanosilver (AgNPs) biosynthesis process}

A total of $3.0 \mathrm{~mL}$ of boiled orange peel were added to $10 \mathrm{~mL}$ of $4.0 \mathrm{mM} \mathrm{AgNO}$ solution. The mixing was done manually; then, the mixture was allowed to stand for 30 minutes in a dark container to reduce photoreduction at room temperature (Annu et al., 2018).

\section{Characteristics of AgNPs using bioreductor sweet orange peel}

The wavelength range of AgNPs data was analyzed using a UV-VIS spectrophotometer to confirm the formation of AgNPs. The color change in the sample, which indicates the formation of AgNPs, was then proven by the UV-VIS spectrophotometer method at a wavelength range of 350$700 \mathrm{~nm}$, which is the SPR (Surface Plasmon Range) of AgNPs range. Sweet orange peel infusion was used as a blank (Annu et al., 2018).

PSA with the DLS (Dynamic Light Scattering) method, also known as light scattering, was used to characterize particles' distribution in a solvent. AgNPs using bioreductor Sweet Orange Peel solution were tested in a sample without dilution. PSA testing was carried out at the Pharmaceutical Technology Laboratory, Faculty of Pharmacy, Islamic University of Indonesia, Yogyakarta.

SEM was used to see the morphology of the nanoparticles formed. AgNPs powder was obtained using AgNPs colloids which were biosynthesized, centrifuged at 10,000 rpm for 15 minutes. The pellets will settle at the bottom of the Effendorf then the pellets will be transferred to the petri dish. Petri dishes filled with pellets were heated using an oven at $60{ }^{\circ} \mathrm{C}$ for 24 hours. The AgNPs powders were taken and then characterized. 


\section{Formulation of AgNPs peel off mask using bioreductor sweet orange peel}

The formula used in this study was developed from the peel-off mask formula, according to (Badnore et al., 2019). The total concentration of humectant used in the study had the same as the Badnore et al. (2019) formula used propylene glycol with a total concentration of $0.5 \%$, but this study used a combination of humectants with a total concentration of $0.5 \%$. The variations of the Propylene Glycol-PEG 400 combination were F1 (0: 100\%); F2 (25\%: 75\%); F3 (50\%: 50\%); F4 (75\%: 25\%) and F5 (100\%: 0).

Tabel 1. Peel off mask formula of AgNPs using bioreductor sweet orange peel that developed from Badnore et al., 2019 with a varying humectant: propylene glycol-PEG 400

\begin{tabular}{lcccccc}
\hline \multirow{2}{*}{\multicolumn{1}{c}{ Ingredients }} & \multirow{2}{*}{ Function } & \multicolumn{5}{c}{ Concentration (\%) } \\
\cline { 3 - 7 } & & F1(0:100) & F2 (25:75) & F3 (50:50) & F4 (75:25) & F5 (100:0) \\
\hline AgNPs & Active substance & 11.6 & 11.6 & 11.6 & 11.6 & 11.6 \\
Polyvinyl Alcohol & Polymer & 13.0 & 13.0 & 13.0 & 13.0 & 13.0 \\
PEG 400 & Humectant & 0.5 & 0.38 & 0.25 & 0.12 & 0.0 \\
Propylene glycol & Humectant & 0.0 & 0.12 & 0.25 & 0.38 & 0.5 \\
Phenoxyethanol & Preservative & 0.1 & 0.1 & 0.1 & 0.1 & 0.1 \\
Parfume & Fragrance & q.s. & q.s. & q.s. & q.s. & q.s. \\
Aquadest & Solvent & 74.8 & 74.8 & 74.8 & 74.8 & 74.8 \\
\hline
\end{tabular}

Polyvinyl alcohol is dissolved in hot water while stirring until homogeneous (mixture 1) (Beringhs et al., 2013). The ratio of water to PVA used is 4:1. Mixture 1 was poured into a mortar and then added polyethylene glycol 400 and propylene glycol were then stirred until homogeneous (mixture 2). Phenoxyethanol is added to mixture 2 and stirred until homogeneous (mixture 3 ). The active substance and the rest of the aqua dest are put in mixture 3 and stirred until homogeneous (mixture 4). Perfume is put into mixture 4 and stirred until homogeneous.

\section{Physical and chemical properties test of peel-off mask Organoleptic}

Observations included consistency, homogeneity, color, and smell (Zhelsiana and Pangestuti, 2016) of the peel-off mask preparation every week for 28 days at room temperature.

\section{The $\mathrm{pH}$ of peel-off mask preparations}

The $\mathrm{pH}$ test was carried out using a $\mathrm{pH}$ meter dipped in a peel-off mask preparation. The $\mathrm{pH}$ meter was slowly rotated until showing a constant $\mathrm{pH}$ value. The value indicated by the $\mathrm{pH}$ meter was recorded. The $\mathrm{pH}$ test was replicated three times. The $\mathrm{pH}$ meter calibration was carried out before testing; the optimum $\mathrm{pH}$ for topical preparations was 4.3-6.8.

\section{Dry time}

Ethical clearance was proposed for testing the dry time of mask preparations. A total of 1.0 grams of the peel-off mask preparation was applied to the arm's skin with a size of $7 \times 7 \mathrm{~cm}$. The drying time of the preparations is calculated from the start of the application to form a film layer using a stopwatch (Zubaydah et al., 2020). The dry time test was replicated three times.

\section{Viscosity of preparations}

A total of $150 \mathrm{ml}$ of peel-off mask preparation was poured into the cup. The viscosity value was measured using the Viscometer Rion with spindle number 2 . The rotor was placed in the center of the cup. After the viscometer was turned on, a 1-minute wait was taken before recording the 
preparation's viscosity results (Puspitasari and Wardhani, 2018). The viscosity test was replicated three times.

\section{Dispersibility test}

A total of 0.5 grams of the peel-off mask preparation was placed on transparent glass (1). The weight of transparent glass (2) to be placed on top of the preparation was scaled. The 1-minute wait was then taken. A load of 50 grams was placed on the transparent glass (2), and then another 1-minute wait was taken. A further load of 50 grams was added until the distribution was constant (Cahyani et al., 2017). The dispersibility test was replicated three times.

\section{Data Analysis}

The data from the physical and chemical properties of the preparations were analyzed using the Shapiro-Wilk test. If the data are normally distributed, then it is followed by the One Way ANOVA test because there was one treatment factor on the difference in the concentration of propylene glycol and PEG 400 during 28 days of storage at room temperature. If the data are not normally distributed, it is tested using Kruskal Wallis; then, if the p-value is found $<0.05$, it is followed by the Mann Whitney test.

\section{RESULT AND DISCUSSION}

The results of the determination of the sweet orange plant that was used came from the Sweet Orange (Citrus sinensis (L.) Osbeck) plant with the synonym Citrus aurantium L. (var.) Sinensis L. The color of sweet orang peel infusion is pale yellow, and the silver nitrate solution is colorless. The color change of the biosynthesis process results in brownish yellow (Figure 1), which indicates the formation of AgNPs, then it was further confirmed using a UV-VIS spectrophotometer instrument. The time required for the formation of AgNPs is 30 minutes, then the wavelength and absorbance can be measured. In the AgNPs measurement, an infusion of sweet orange peel was used as a blank and measured in the wavelength range of 350-700 nm (Annu et al., 2018).

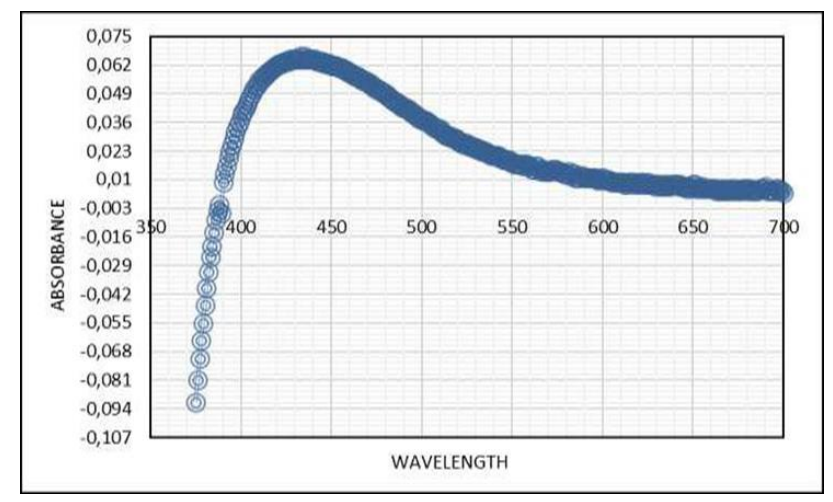

Figure 1. The wavelength of AgNPs using bioreductor sweet orange peel in the SPR range of 350-700 $\mathrm{nm}$ obtained the absorption peak at a wavelength of $435 \mathrm{~nm}$. The color of sweet orange peel infusion is pale yellow, silver nitrate solution is colorless, and the color of AgNPs solution is brownish yellow

The AgNPs wavelength spectra (Figure 1) were different from silver nitrate wavelength spectra, where the $\mathrm{AgNO}_{3}$ solution showed a wavelength peak at $229 \mathrm{~nm}$. Simultaneously, the AgNPs biosynthesized using sweet orange peel showed a wavelength peak at $435 \mathrm{~nm}$. According to (Annu et al., 2018), the results of AgNPs using bioreductor sweet orange peel showed a wavelength peak at 442-460 nm. Sweet orange peel, as bioreductor, may have a different percentage of active 
substances from other types of sweet oranges. There are citric acid and ascorbic acid ones along with polyphenolic compounds (Hungund, 2015). Several factors affect the concentration of ascorbic acid in natural material: storage period, sun exposure, and heating factors. The process of washing and ripening the fruit by heating can reduce the ascorbic acid content (Febrianti et al., 2015). According to Prathna et al. (2011), AgNPs showed the absorption of UV-VIS waves in the $400-500 \mathrm{~nm}$ range, so it can be said that the sweet orange peel infusion in this study can be used as a bioreductor and succeeded in forming AgNPs formation.

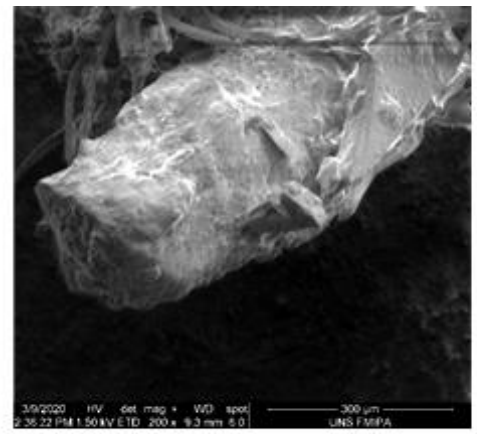

(a)

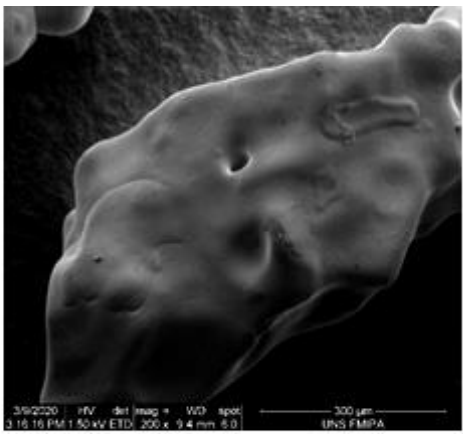

(b)

Figure 2. The results of SEM analysis of AgNPs using bioreductor sweet orange peel (a) and silver nitrate powder (b) with a magnification of 200 times

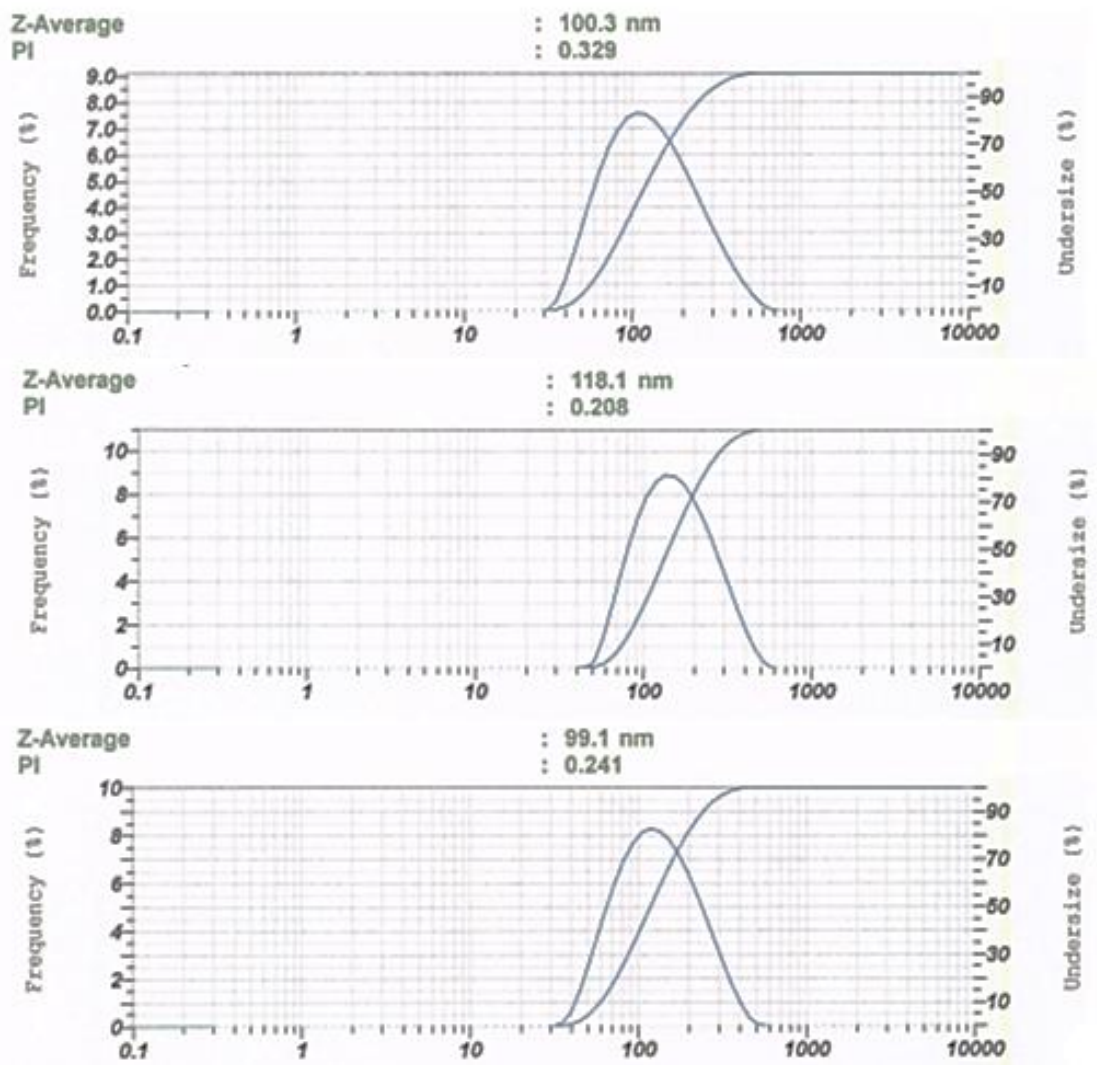

Figure 3. The results of Particle Size Analysis of AgNPs using bioreductor sweet orange. The average of the particle of nanosilver is $106 \pm 10.6 \mathrm{~nm}$ 
Nanoparticles with a range size of 1-100 $\mathrm{nm}$ are included in the ultrafine particle category, while nanoparticles with a range size of $100-2500 \mathrm{~nm}$ are included in the fine particle category (Hasri et al., 2009). The results showed that the AgNPs from the biosynthesis results have an average particle size of $106 \pm 10.6 \mathrm{~nm}$ (Figure 3). It indicated that the particle size of AgNPs in this study was categorized as fine particles. Previous studies reported that the particle size of AgNPs from the biosynthesis of sweet orange peels was $86.4 \mathrm{~nm}$ (Annu et al., 2018); the difference was probably due to the type of sweet orange that was used as a bioreductor agent. The active substance in the infusion of sweet orange peel that plays a role in converting AgNPs is ascorbic acid (Hungud, 2015). Several factors can affect ascorbic acid content in natural materials, including storage time, sun exposure, and heating factors (Febrianti et al., 2015).

In this study, there was no quantitative test to measure ascorbic acid content, so it is still unsure whether the ascorbic acid content factor affects the size of the particles produced. The polydispersity index (PI) value is a condition in the distribution of particles that describes the level of uniformity of the particle size of a component. The small value of the polydispersity index indicated that particles' distribution in a component has a uniform level of uniform size. PI value described meeting the requirements if the value is between 0.0-0.5. Nanoparticles have an acceptable limit of the polydispersity index value of less than 0.25 (Ferdiansyah et al., 2017). The average PI of AgNPs value in this study is PI $0.26 \pm 0.06$.

The morphological characteristics of the AgNPs were observed using SEM instruments. In this study, silver nitrate powder was used as a control (Figure 2). SEM presented particle morphology at 200 times magnification. Figure 2 shows that the biosynthetic process in this study resulted in a rod-shaped nanosilver. The significant difference between biosynthesized nanosilver and silver before being biosynthesized lies on their surface. In Figure 2, the surface of silver was very smooth, and there were no particles that coat it. However, a biological material or compound coated the formed nanosilver's surface, which is thought to be derived from the $C$. sinensis capping agent.

\section{Physical and chemical properties test of peel of mask Organoleptic}

The organoleptic test results showed that the peel-off mask characteristics were almost identical between five formulas: browny, thick, and odorless. The brown color of the peel-off mask is caused by the active substance of the AgNPs biosynthetic solution using sweet orange peel. The organoleptic test results showed no significant difference between the peel-off mask formulas for 28 days of storage at room temperature.

\section{The $\mathrm{pH}$ value of peel-off mask preparation}

The $\mathrm{pH}$ value is used to determine the preparation's acceptability to be applied topically to the skin surface (Ermawati and Wulandari, 2019). The $\mathrm{pH}$ testing is related to the comfort and safety of the preparation when applied to the skin. If the preparation's $\mathrm{pH}$ is too acid, it will irritate the skin, whereas if the $\mathrm{pH}$ of the preparation is too alkaline, it will cause dry and scaly skin (Djajadisastra et al., 2009). In topical preparations, the $\mathrm{pH}$ must be in the skin $\mathrm{pH}$ range of 4.3-6.0 to avoid skin irritation (Budiman et al., 2017).

The $\mathrm{pH}$ test results in Table 2 showed that the five peel-off mask formulas fulfill the $\mathrm{pH}$ requirement for skin application. The $\mathrm{pH}$ test results for Sariayu ${ }^{\circledR}$ peel-off mask preparation were 4.9 as the comparative product. The statistical analysis results showed that the difference in the concentration of propylene glycol and PEG 400 did not have a significant effect on the $\mathrm{pH}$ value (p>0.05). However, the $\mathrm{pH}$ of the preparation for 28 days of storage at room temperature decreased. A decrease in $\mathrm{pH}$ value during storage can occur due to carbon dioxide $\left(\mathrm{CO}_{2}\right)$ influence which reacts with the water phase to become acidic (Septiani et al., 2011). The decrease in $\mathrm{pH}$ can also be caused by ion contamination from the ingredients used in the formulation of both positive 
and negative ions, affecting the acidity or alkalinity of the preparation (Mardhiani et al., 2018). F2 with a ratio of propylene glycol-PEG 400 (25\%:75\%) did not show a significant decrease in $\mathrm{pH}$ at week 1 to week 3 and only showed a significant decrease in $\mathrm{pH}$ at week 4.

\section{Dry time}

The dry time criterion for peel-off mask preparations is 15-30 minutes (Istiqomah and Anindhita, 2018). The results of the dry time of the five peel-off mask formulas were included in the required dry time criteria. The statistical analysis results showed that the difference in the concentration of propylene glycol and PEG 400 has a significant effect on the peel-off mask preparation's dry time results $(\mathrm{p}<0.05)$. The greater propylene glycol concentration causes the dry time of preparation to become longer because propylene glycol functions to maintain moisture by reducing water evaporation from the preparation (Andini et al., 2017). However, during 28 days of storage at room temperature, dry time, each formula did not show a significant difference.

\section{Viscosity of the peel-off mask}

Viscosity is the main character related to skin application and the preparation's stability (Beringhs et al., 2013). Viscosity is a factor that can affect the dispersibility parameters and the release of the active substance from the gel. Gel preparations with optimum viscosity will disperse the active substance (Sulastri et al., 2016). Gel with too low viscosity causes the contact time with the skin is not long enough, so the active ingredient's activity is not optimal; high viscosity increases the application site's retention time and decreases the spreadability (Sulastri et al., 2016). The viscosity criteria for gel mask preparations is 50-1000 d.Pas (Istiqomah and Anindhita, 2018). The comparative peel-off mask product, Sariayu ${ }^{\circledR}$, showed a viscosity of 1090 d.Pas.

The results of statistical analysis showed that the difference in the concentration of propylene glycol and PEG 400 had a significant effect on the viscosity between five formulas ( $p$ $<0.05$ ), but during storage for 28 days did not significantly affect the viscosity of the five peel off mask formulas $(\mathrm{p}>0.05)$. The viscosity values that were significantly different between formulas were influenced by the concentration of propylene glycol and PEG 400. Formulas with $100 \%$ propylene glycol or PEG 400 concentrations show a high viscosity value, but the propylene glycolPEG 400 concentration of 50\%: 50\% shows the lowest. Propylene glycol and PEG 400 may be both hygroscopic (Andini et al., 2017). The increased hygroscopic ability of formulas with a combination of propylene glycol -PEG 400 is influenced by the presence of hydrophilic groups such as $\mathrm{OH}^{-}, \mathrm{COOH}^{-}$, and $\mathrm{SO}_{3}^{-}$(Marx and Barillo, 2014).

\section{The dispersibility of the peel-off mask preparation}

The dispersibility test was carried out to determine the ability to spread peel-off masks when applied to the skin and secreting the gel from the cosmetic packaging. A good gel takes less time to disperse and will have a high dispersibility value. The spreadability value required for topical preparations is between 5.0-7.0 cm (Sulastri et al., 2016). The wider spreadability of gel will increase the active substance's ability to spread and contact the skin (Mardhiani et al., 2018). The test results of the five peel-off mask formulations have met the dispersibility criteria for topical preparations. The spreadability test results of Sariayu ${ }^{\circledR}$ peel off mask as comparative product was $5.65 \mathrm{~cm}$. These results are in the range of dispersibility criteria for topical preparations.

The statistical analysis results showed that the difference in propylene glycol and PEG 400 concentrations significantly affected the dispersibility value between formulas $(p<0.05)$. The value of the spreadability of the preparation is inversely proportional to the viscosity. Higher viscosity value caused to make smaller dispersibility value, and vice versa (Mardhiani et al., 2018). 
The preparations' storage length during 28 days had a significant effect on the preparations' dispersibility $(\mathrm{p}<0.05)$. This significant difference only occurred in F2 with varying propylene glycol-PEG 400 (25\%: 75\%) concentrations every week.

Table 2. Results of physical and chemical properties of nanosilver biosynthesis gel during 28 days storage with varying propylene glycol-PEG 400 concentrations

\begin{tabular}{|c|c|c|c|c|c|c|c|c|}
\hline \multirow{3}{*}{$\begin{array}{c}\text { Formula } \\
\text { PG-PEG } \\
\quad 400\end{array}$} & \multicolumn{8}{|c|}{ Physical and Chemical Properties of Peel-off Mask of AgNPs } \\
\hline & \multicolumn{2}{|c|}{ Viscosity (d.Pas) } & \multicolumn{2}{|c|}{ pH value } & \multicolumn{2}{|c|}{ Dispersibility $(\mathbf{c m})$} & \multicolumn{2}{|l|}{$\begin{array}{l}\text { Dry time } \\
\text { (minute) }\end{array}$} \\
\hline & Week-1 & Week-4 & Week-1 & Week-4 & Week-1 & Week-4 & Week-1 & Week-4 \\
\hline $1(0: 100 \%)$ & $1080^{\mathrm{a}} \pm 28.87$ & $1030^{\mathrm{a}} \pm 34.64$ & $6.0 \pm 0.0$ & $5.7 \pm 0.06$ & $5.38 \pm 0.14$ & $5.58 \pm 0.08$ & $19^{\mathrm{a}} \pm 0.14$ & $19 \pm 0.58$ \\
\hline $2(25: 75 \%)$ & $753^{\mathrm{b}} \pm 5.77$ & $607 \pm 60.28$ & $5.9 \pm 0.06$ & $5.6 \pm 0.06$ & $5.88 \pm 0.03$ & $6.68 \pm 0.16$ & $18^{\mathrm{b}} \pm 0.58$ & $18 \pm 0.58$ \\
\hline $3(50: 50 \%)$ & $720^{\mathrm{b}} \pm 26.46$ & $627 \pm 55.08$ & $5.9 \pm 0.0$ & $5.7 \pm 0.10$ & $6.02 \pm 0.13$ & $6.45 \pm 0.18$ & $19^{b} \pm 0.58$ & $19 \pm 0.58$ \\
\hline $4(75: 25 \%)$ & $687^{\mathrm{b}} \pm 32.15$ & $580 \pm 26.46$ & $5.9 \pm 0.06$ & $5.6 \pm 0.06$ & $6.13 \pm 0.15$ & $6.62 \pm 0.13$ & $20^{\mathrm{b}} \pm 0.00$ & $20 \pm 0.58$ \\
\hline $5(100: 0 \%)$ & $753^{\mathrm{b}} \pm 5.77$ & $817 \pm 57.74$ & $5.9 \pm 0.06$ & $5.7 \pm 0.11$ & $5.88 \pm 0.08$ & $5.80 \pm 0.10$ & $20^{\mathrm{b}} \pm 0.58$ & $20 \pm 0.58$ \\
\hline
\end{tabular}

\section{CONCLUSION}

The combination of propylene glycol and polyethylene glycol 400 gave a significant effect on the physical properties of the peel-off mask of AgNPs using bioreductor sweet orange peel, including viscosity and spreadability, and dry time but did not affect to $\mathrm{pH}$ of the preparation during 28 days of storage at room temperature. The formula with a humectant combination ratio of propylene glycol-PEG 400 (75\%: $25 \%)$ and (25\%: $75 \%)$ fulfills the gel preparation's physical and chemical properties requirements during 28 days of storage. Further, it is necessary to test the preparation's stability and its antibacterial activity. The combination of PG-PEG 400 concentrations decreased the viscosity and increased the dispersibility of peel-off mask preparation. Meanwhile, a higher concentration of propylene glycol caused the dry time of preparation to become longer.

\section{REFERENCES}

Abbas, Z., \& Sachin, S. (2012). Development of an antimicrobial gel formulation for topical delivery using silver nanoparticle. Indian Journal of Novel Drug Delivery, 4(1), 2-16

Andini, T., Yusriadi, Y., \& Yuliet, Y. (2017). Optimasi pembentuk film polivinil alkohol dan humektan propilen glikol pada formula masker gel peel off sari buah labu kuning (Cucurbita moschata Duchesne) sebagai antioksidan. Jurnal Farmasi Galenika (Galenika Journal of Pharmacy) (e-Journal), 3(2), 165-173. https://doi.org/10.22487/j24428744.0.v0.i0.8773

Annu, Ahmed, S., Kaur, G., Sharma, P., Singh, S., \& Ikram, S. (2018). Fruit waste (peel) as bioreductant to synthesize silver nanoparticles with antimicrobial, antioxidant and cytotoxic activities. Journal of Applied Biomedicine, 16(3), 221-231. https://doi.org/10.1016/j.jab.2018.02.002

Badnore, A. U., Sorde, K. I., Datir, K. A., Ananthanarayan, L., Pratap, A. P., \& Pandit, A. B. (2019). Preparation of antibacterial peel-off facial mask formulation incorporating biosynthesized silver nanoparticles. Applied Nanoscience, 9(2), 279-287. https://doi.org/10.1007/s13204-018-0934-2

Beringhs, A. O. R., Rosa, J. M., Stulzer, H. K., Budal, R. M., \& Sonaglio, D. (2013). Green clay and aloe vera peel-off facial masks: Response surface methodology applied to the formulation design. AAPS PharmSciTech, 14(1), 445-455. https://doi.org/10.1208/s12249-013-9930-8

Budiman, A., Aulifa, D. L., Kusuma, A. S. W., Kurniawan, I. S., \& Sulastri, A. (2017). Peel-off gel formulation from black mulberries (Morus nigra) extract as anti-acne mask. National Journal of Physiology, Pharmacy and Pharmacology, 7(9), 987-994. https://doi.org/10.5455/njppp.2017.7.0413123052017 
Cahyani, I. M., Dwi, I., \& Putri, C. (2017). Formulation of peel-off gel from extract of curcuma heyneana Val \& Zijp using carbopol 940. Journal of Pharmaceutical and Medicinal Sciences, $2(2), 48-51$

Campbell, C. S. J., Contreras-Rojas, L. R., Delgado-Charro, M. B., \& Guy, R. H. (2012). Objective assessment of nanoparticle disposition in mammalian skin after topical exposure. Journal of Controlled Release: Official Journal of the Controlled Release Society, 162(1), 201-207. https://doi.org/10.1016/j.jconrel.2012.06.024

Djajadisastra Abdul; NP, Dessy, J. M. (2009). Formulasi gel topikal dari ekstrak nerii folium dalam sediaan anti jerawat. JFIOnline, 4(4)

Dreno, B., Martin, R., Moyal, D., Henley, J. B., Khammari, A., \& Seité, S. (2017). Skin microbiome and acne vulgaris: Staphylococcus, a new actor in acne. Experimental Dermatology, 26(9), 798-803. https://doi.org/10.1111/exd.13296

Ermawati, D. E., \& Wulandari, C. (2019). Influence of CMC-Na concentration to physical properties of SNEDDS kersen leaves ethanolic extract gel. IOP Conference Series: Materials Science and Engineering, 578(1). https://doi.org/10.1088/1757-899X/578/1/012047

Febrianti, N., Yunianto, I., \& Dhaniaputri, R. (2015). Kandungan antioksi dan asam askorbat pada jus buah-buahan tropis. Jurnal Bioedukatika, $3(1), \quad 6$. https://doi.org/10.26555/bioedukatika.v3i1.4130

Ferdiansyah, F., Heriyanto, H., Wijaya, C. H., \& Limantara, L. (2017). Pengaruh metode nanoenkapsulasi terhadap stabilitas pigmen karotenoid dan umur simpan minyak dari buah merah (Pandanus conoideus L). Agritech, 37(4), 369. https://doi.org/10.22146/agritech.15467

Hasri, Dini, I., \& Subaer, S. P. J. N. (2009). Biosynthesis of silver nanoparticles made from green tea leaf extract (Camellia sinensis). Materials Science Forum, 967, 161-167

Hungund, B. (2015). Comparative evaluation of antibacterial activity of silver nanoparticles biosynthesized using fruit juices. Journal of Nanomedicine \& Nanotechnology, 06(02). https://doi.org/10.4172/2157-7439.1000271

Istiqomah, N., \& Anindhita, M. A. (2018). Pengaruh penggunaan hidroksi propil metil selulosa (HPMC) sebagai Gelling Agent terhadap sifat fisik masker Peel Off ekstrak daun sirih (Piper betle L.). Pena Jurnal Ilmu Pengetahuan Dan Teknologi, 32(2), 49-58

Korani, M., Rezayat, S. M., Gilani, K., Arbabi Bidgoli, S., \& Adeli, S. (2011). Acute and subchronic dermal toxicity of nanosilver in guinea pig. International Journal of Nanomedicine, 6, 855-862. https://doi.org/10.2147/IJN.S17065

Mardhiani, Y. D., Yulianti, H., Azhary, D. P., \& Rusdiana, T. (2018). Formulasi dan stabilitas sediaan serumdari ekstrak kopi hijau (Coffea Canephora Var. Robusta)sebagai antioksidan. Indonesia Natural Research Pharmaceutical Journal Universitas 17 Agustus 1945 Jakarta, 2(2), 19-33

Marx, D. E., \& Barillo, D. J. (2014). Silver in medicine: the basic science. Burns, 40, S9-S18. https://doi.org/https://doi.org/10.1016/j.burns.2014.09.010

Prathna, T. C., Chandrasekaran, N., Raichur, A. M., \& Mukherjee, A. (2011). Biomimetic synthesis of silver nanoparticles by Citrus limon (lemon) aqueous extract and theoretical prediction of particle size. Colloids and Surfaces B: Biointerfaces, 82(1), 152-159. https://doi.org/https://doi.org/10.1016/j.colsurfb.2010.08.036

Pulit-Prociak, J., Grabowska, A., Chwastowski, J., Majka, T. M., \& Banach, M. (2019). Safety of the application of nanosilver and nanogold in topical cosmetic preparations. Colloids and $\begin{array}{llll}\text { Surfaces } & B: & \text { Biointerfaces, } & 183,\end{array}$ https://doi.org/https://doi.org/10.1016/j.colsurfb.2019.110416

Puspitasari, A. D., \& Wardhani, E. I. K. (2018). Evaluasi karakteristik fisika-kimia dan nilai SPF lotion tabir surya ekstrak daun kersen (Muntingia calabura L.). Jurnal Riset Teknologi Industri, 12(2), 150-158. https://doi.org/10.26578/jrti.v12i2.4242 
Septiani, S., Wathoni, N., \& Mita, S. R. mita. (2011). Formulasi sediaan masker gel antioksidan dari ekstrak etanol biji belinjo. Fakultas Farmasi Universitas Padjajaran, 2-4

Singh, B. R. (2013). Antimicrobial sensitivity assay and antimicrobial chemotherapy in animals : a Practical approach. Diseases of Animals: Diagnosis and Management, March, 1-25. https://doi.org/10.13140/RG.2.1.2987.4322

Sulastri, E., \& Rahmiyati Jurusan Farmasi Fakultas, D. (2016). Pengaruh pati pragelatinasi beras hitam sebagai bahan pembentuk gel tehadap mutu fisik sediaan masker gel peel off. Jurnal Pharmascience, 03(02), 69-79. http://jps.unlam.ac.id/

Velasco, M. V. R., Vieira, R. P., Fernandes, A. R., Dario, M. F., Pinto, C. A. S. O., Pedriali, C. A., Kaneko, T. M., \& Baby, A. R. (2014). Short-term clinical of peel-off facial mask moisturizers. International Journal of Cosmetic Science, 36(4), 355-360. https://doi.org/10.1111/ics.12133

Vieira, R. P., Fernandes, A. R., Kaneko, T. M., Consiglieri, V. O., Pinto, C. A. S. D. O., Pereira, C. S. C., Baby, A. R., \& Velasco, M. V. R. (2009). Physical and physicochemical stability evaluation of cosmetic formulations containing soybean extract fermented by Bifidobacterium animalis. Brazilian Journal of Pharmaceutical Sciences, 45(3), 515-525. https://doi.org/10.1590/S1984-82502009000300018

Williams, A. C., \& Barry, B. W. (2004). Penetration enhancers. Advanced Drug Delivery Reviews, 56(5), 603-618. https://doi.org/https://doi.org/10.1016/j.addr.2003.10.025

Zhelsiana, D. A., \& Pangestuti, Y. S. (2016). Formulasi dan evaluasi sifat fisik masker gel peel-off lempung bentonite. The 4 Th Univesity Research Coloquium, 42-45

Zubaydah, S., Ode, W., \& Septi Fandinata, S. (2020). Formulasi sediaan masker gel peel-off dari ekstrak buah tomat (Solanum Lycopersicum L.) beserta uji aktivitas antioksidan. Journal Syifa Sciences and Clinical Research, 2(2), 73-82. https://doi.org/10.37311/jsscr.v2i2.6980 
